\title{
Insurgency and institutionalization: the Polanyian countermovement and Chinese labor politics
}

\author{
Eli Friedman \\ Cornell University
}

\begin{abstract}
Why is it that in the nearly 10 years since the Chinese central government began making symbolic and material moves towards class compromise that labor unrest has expanded greatly? In this article I reconfigure Karl Polanyi's theory of the coutermovement to account for recent developments in Chinese labor politics. Specifically, I argue that countermovements must be broken down into two constituent but intertwined "moments": the insurgent moment that consists of spontaneous resistance to the market, and the institutional moment, when class compromise is established in the economic and political spheres. In China, the transition from insurgency to institutionalization has thus far been confounded by conditions of "appropriated representation," where the only worker organizations allowed to exist are those within the state-run All China Federation of Trade Unions. However, in drawing on two case studies of strikes in capital-intensive industries in Guangdong province, I show that the relationship between insurgency and institutionalization shifted between 2007 and 2010.
\end{abstract}

Keywords China. Labor. ACFTU. Polanyi. Social movements. Unions

The first decade of the twenty first century has resulted in seemingly contradictory trends in the dynamics of labor politics in China. On the one hand, the central government and many of the state-controlled unions within the All China Federation of Trade Unions (ACFTU) have been taking an increasingly pro-labor position- even if local governments maintain a strong alliance with capital. The national 5-year plan passed in 2005 called for changes in the country's development model with increased focus on raising wages to increase domestic consumption. Two landmark pieces of labor legislation were enacted in 2008, and there have been consistent and large increases in the minimum wage. On the other hand, labor unrest among migrant workers continued to expand dramatically during this time period. What explains continual high levels of worker insurgency even as the state was moving in a prolabor direction?

In this article, I argue that Karl Polanyi's (1944) theory of the countermovement is useful in understanding labor politics in contemporary China-but only to a point. Polanyi claims that an expansion of the self-regulating market, and in particular commodifiction of land, labor, and money, implies the pursuit of a "stark utopia." If followed to its logical conclusion, this economic program would imply the destruction of society and the biosphere. In this conceptualization of the problem, society's revolt against the self-regulating market is born of necessity, since otherwise the world would be destroyed. And such a theory seems to go a long way in explaining what has happened in China over the past 30 years. As market forces were unleashed, social upheavals resulting from the commodification of labor burst on the political scene. In what appeared to be a striking confirmation of Polanyian theory (Wang 2008), the state began to respond by slowing down market reforms and increasing social spending and legal protections for workers. And yet, the theory fails to explain why labor remains highly commodified or worker insurgency continues to expand-in short, it cannot fully account for the unfolding contours of labor politics in contemporary China. 
As Burawoy has argued, "Polanyi gives us a signpost to an architecture of counterhegemony even as he fails to appreciate the obstacles it must face." (Burawoy 2003, p. 231) In other words, the theory of the countermovement does a poor job of accounting for politics (Liu 2011, p. 22). To address this problem, I argue that countermovements against commodification need to be broken down into two constituent components: the "insurgent moment" when workers and others negatively affected by marketization rebel and engage in non-regularized forms of contention; and the "institutional moment" when decommodification of labor comes to be institutionalized at the social level and the working class is politically incorporated by the state. By making such a distinction, we can see that it is not inevitable that market logic will be subordinated to conscious human action, but rather that it will only come about as a result of successful political contestation.

The labor politics of contemporary China are an ideal site for observing the dialectical interaction between the insurgent and institutional moments of the countermovement. This is the case in large part because the "obstacles," as Burawoy refers to them, are so profound and therefore present the dilemma in exaggerated form. In China, the key obstacle to institutionalizing the countermovement is the strong alliance between the local state and capital. Although such an alliance is not unusual in countries undergoing capitalist industrialization, the key difference is that Chinese workers do not have the opportunity to construct collective power in the form of independent unions. Over the past three decades, a new class of migrant workers has come into existence under conditions of "appropriated representation," (defined in more detail below) in which the ACFTU has a rock solid monopoly on their political representation-a monopoly both granted and enforced by the coercive power of the state. Given union heteronomy vis-a-vis capital within the enterprise and the state at higher levels, Chinese workers do not have autonomous and organized power on the shopfloor. Since there is no sustainable countervailing force at the point of production, there are endemic legal violations in the workplace; thus, potentially pro-labor legislation and administratively imposed collective contracts frequently go unenforced. Labor remains highly commodified and workers are forced to take autonomous and radical collective action in order to have their grievances addressed. However, thus far such autonomous resistance remains highly cellular and unable to coerce capital consistently into abiding by the law. Consequently, we can see how the particular features of political representation for the working class can result in a situation in which insurgency does not translate in any direct or necessary way to the institutionalization of the countermovement.

In this article, I compare two strikes that in many ways are similar-the little known Ascendant Elevator Company ${ }^{1}$ strike and the famous Nanhai Honda strike- but that produced very different outcomes. In the Ascendant case, we see insurgent workers resisting commodification, encountering inaction from the union, failing to win any victories ... and then striking again. In this case, we see the countermovement "stalled" at the insurgent moment. Twoand-a-half years later in the Honda case, the strikers were able to "boomerang" (Keck and Sikkink 1998) around repressive local authorities to win the support of the provincial and central state, which then opened up the space for 
better organization and greater militancy. As a strike wave engulfed the entire foreign-owned auto industry in China in the summer of 2010, the capacity for the local state and union organizations to maintain low-cost and highly repressed labor - already challenged by the myriad daily labor conflicts around the country-began to crumble. Significantly, the position of the higher levels of the state had evolved between late 2007 (when the Ascendant strike took place) and 2010, affecting both the process and outcome of the strikes. The Honda strike dissolved the image of a unified state edifice, as the central and provincial government showed relative tolerance towards the workers while the local state resorted to coercion in a failed attempt to bring the deadlock to a close. The 2010 strike wave marked an important turning point for Chinese labor politics, and in the trajectory of the nation's political economy more broadly.

My main argument in this article is as follows. The transition from the insurgent to institutional moment of countermovements can-particularly in non-democratic states-only be accomplished with the accumulation of countless, often relatively anonymous, and seemingly apolitical instances of social struggle. As we can see in China, it is only under particular political and economic conditions that the capitalist state, or at least significant segments of it, will be ready for compromise. For years, a strong alliance between capital and the lowest levels of the Chinese state resulted in strikes being dealt with either through police repression or through an ad-hoc system of mediation by union and government officials that was focused almost exclusively on resuming production, regardless of the outcome for workers. But during the first 30 years of China's transition to capitalism, increasing iterative flashes of worker insurgency have not merely dissipated into the ether. Rather, in a complex and highly mediated process, residual particles of insurgency have settled on the political field, eventually re-making the landscape and changing the attitudes of the state towards wildcat strikes. Thus, by 2010 the Chinese central government and Guangdong provincial authorities were not only ready to seek a new model of accumulation in the Pearl River Delta, but were willing to (indirectly) ally with insurgent workers in attempting to realize this goal. Just such an alliance, conditional and ephemeral as it may have been, emerged in the course of the Nanhai Honda strike, which in turn allowed the strikers to win economic demands and to begin to develop political goals. In large part because of this small political opening, the character of protest in the 2010 strike wave displayed some unusual (if not unprecedented) tendencies, most significantly that demands were offensive rather than defensive in nature. By comparing the strikes at Ascendant and Nanhai Honda, we can see that the position of the provincial and central authorities shifted in the intervening two and a half years, even if the lowest level of the state remained committed to low-cost labor. However, even if Honda employees won economic gains that eluded the Ascendant strikers, we see that all levels of the state and union remain vigilant about the development of autonomous bases of worker power. Although economic gains were made in the 2010 strike wave, worker disillusionment with unions from the enterprise level on up persists, and a transition to rationalized forms of labor relations remains problematic.

I next briefly discuss the character of worker insurgency and the state's response, followed by a reconceptualization of the Polanyian countermovement and then an overview of the problematic relationship between workers and unions. I then present data on strikes and their consequences in the Ascendant Elevator and Nanhai Honda plants. I make use of the reconfigured framework to explain divergent outcomes in the two strikes, as well as to analyze 
the ongoing political consequences of the 2010 strike wave.

\section{Worker insurgency in China}

More than 30 years into its project of market reform, it is no longer hyperbolic to refer to China as the epicenter of global labor unrest (Silver and Zhang 2009). Although the massive upheavals that accompanied the privatization and reform of the state- owned sector (Cai 2002; Chen 2000, 2003a; Hurst 2004, 2009; Lee 2000, 2002; Solinger 2009) have more or less subsided, ${ }^{2}$ labor conflict in the private sector remains high. There are no official statistics on the number of strikes and reporting on such conflicts presents potentially high risks for reporters (Hassid 2008), but we do know that the number of officially reported labor disputes has increased rapidly in recent years (see Fig. 1). If the state has had a degree of success in inculcating legalistic and individualized modes of contention among migrant workers (Friedman and Lee 2010; Lee 2007), high levels of radical collective action such as strikes, road blockages, and riots continue to present a challenge to the state. ${ }^{3}$

And yet, even if worker unrest is widespread it remains fundamentally cellular in character (Lee 2007). Much as has been the case in other East Asian countries during industrialization, the Chinese state is committed to the political exclusion of workers

\section{Labor Disputes in China 1996 - 2009}

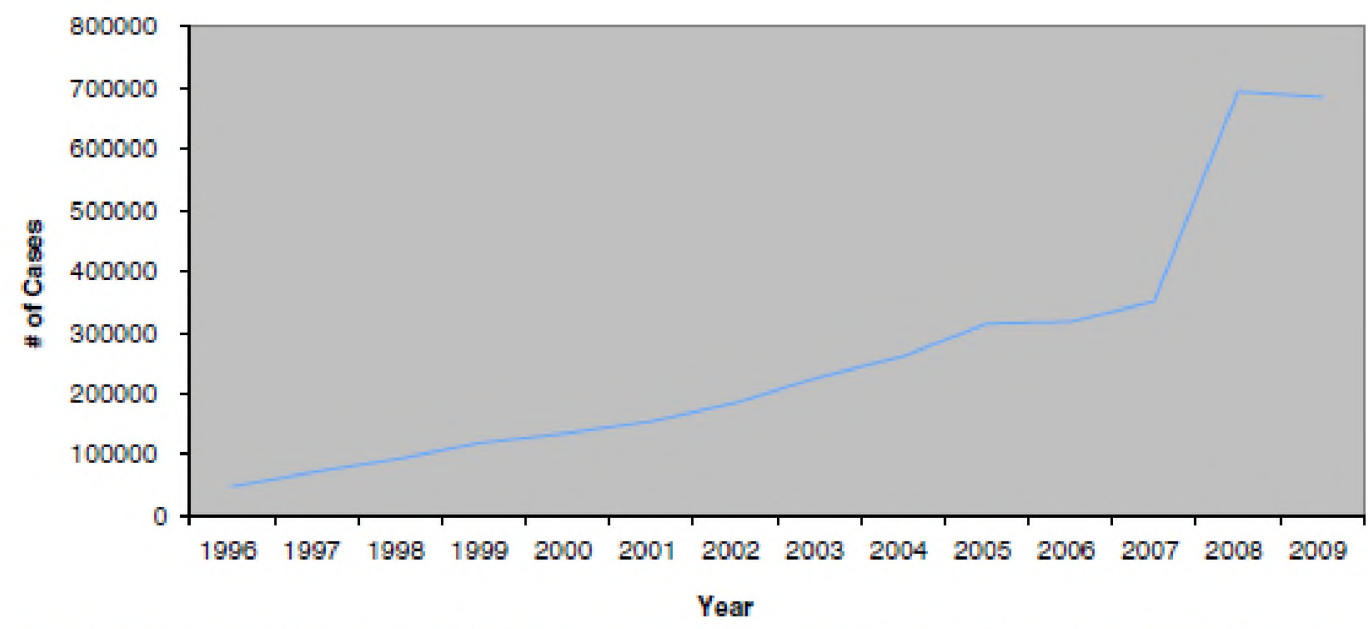

Fig. 1 Labor Disputes in China 1996-2009. Source: zhongguo laodong tongji nianjian 20 10. [China Labor Statistical Yearbook 2010] Beijing: zhongguo tongji chubanshe

(Deyo 1987, 1989; Koo 2001), and they have thus far been unable to construct durable independent organization across space or time. Given their strong interest in maintaining growth (Li and Zhou 2005), local officials continue to collude with capital in subverting the law, as worker power is either weak or ephemeral. Despite some exceptional instances of cross-workplace organizing (Chan and Pun 2009; Leung and Pun 2009), cells of worker activism have hardly formed into

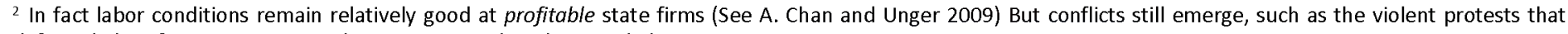
defeated plans for privatization at the Tonggang and Linzhou steel plants in 2009.

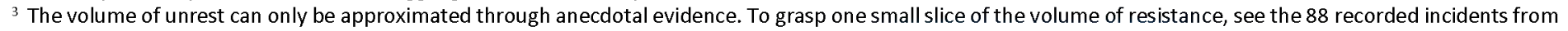
the first half of 2011 on China Labour Bulletin's map of worker unrest, available in Chinese at: http://www.clb.org.hk/schi/
} 
"tissues."

I conceive of migrant worker resistance in China as an insurgency rather than a social movement. "Social movements" as conceived of in classic works by political process theorists (Tarrow 1998; McAdam et al. 2001; McAdam 1982; Andrews 2004; Tilly 2004) generally display the following characteristics: 1) Relatively coherent political program and well-articulated goals; 2) A preponderance of formal "social movement organizations" that are necessary in articulating said goals (Burstein and Linton 2002) available in liberal democracies (e.g., through public marches, media outreach, political lobbying, etc.). These scholars of course acknowledge that there are all sorts of non-institutionalized politics that are not social movements, as indicated by the more general concept of "contentious politics" (Tilly and Tarrow 2007). I, however, follow Ching Kwan Lee in adopting Guha's (1983a, b) more specific term of “insurgency." Worker unrest in China is cellular (Lee 2007), dispersed, fractured, and ephemeral, and does not have consistent, durable, or formalized organization, a well-articulated program, or any identifiable leadership.

I am specifically interested in the outcomes of insurgency, an area in which there is already a well-developed body of literature (Giugni 2004; Goldfield 1989; Snow and Cress 2000; Soule et al. 1999; Tilly 1999). While most of this scholarship focuses on policy outcomes in liberal democracies and is therefore less immediately relevant to this study, there is growing work on contention in authoritarian contexts (Alimi 2009). As far as outcomes specifically are concerned, much of this work is focused on democratization (Schock 2005; Slater 2009) or consequences of particular small scale incidents of contention (Cai 2010). While the dynamics of mobilization and movement-state interaction are of course quite different in such highly repressive environments, studying pro-democracy movements or localized contention still allows the analyst to compare demands with outcomes. Methodologically, studying the politics of a countermovement requires that I situate the outcomes of particular instances of contention within the broader political and economic context (i.e.,. the specific content and dynamics of mobilization are insufficient to explain outcomes). By employing this approach, it is possible to grasp better the major changes brought about by disorganized insurgency (Piven and Cloward 1977).

\section{A new compromise?}

If from the perspective of local governments, worker unrest is an annoyance and short-term threat to profitability, from the perspective of Beijing the generalized discontent among the new working class appears more threatening. Although the 1990s were characterized by a full throttle market assault on state-owned enterprises (Gallagher 2004, 2005) as well as public health (Blumenthal and Hsiao 2005) and education (Chan and Mok 2001; Mok 2000), by the early 2000 s a shift in rhetoric began to emerge from the leadership in Beijing. The Hu-Wen administration that came into power in 2002 soon adopted "scientific development," "harmonious society," and "putting people first"

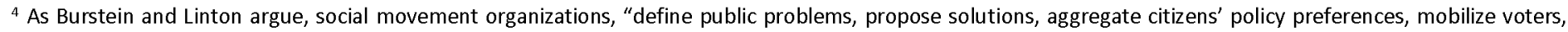

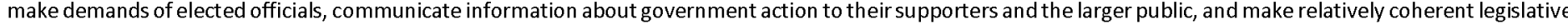

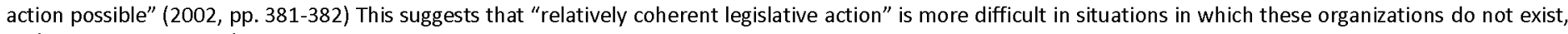
such as contemporary China.
} 
(yirenweiben) as key slogans. The central leadership was concerned with addressing the ecological destruction, stark social and economic polarization, and intensifying social conflict that had resulted from years of profound commodification of social life.

But it was not merely a shift in rhetoric, as the government began to enact a series of policies meant to blunt the edges of the bare-knuckled capitalism that had emerged in the reform era. The Eleventh Five-Year Plan-a roadmap for the state's development policy-called for increasing wages and domestic consumption, and for the first time stated that economic growth is not equivalent to economic development (Fan 2006, p. 710). Starting in the early 2000s, a series of policy initiatives sought to reduce inequality, including a reduction and then elimination in the agricultural tax, an increase in subsidies for rural health and education (Wang 2008, p. 23), and increased spending on pensions for urban residents (Frazier 2010). In 2007 the Labor Contract Law was passed against vociferous opposition from domestic and especially foreign capital that, among other things, aimed to enhance the stability of employment for long-time employees and required that all employees have labor contracts (Chan 2009; Cooney et al. 2007; Wang et al. 2009). After a brief pause during the economic crisis in 2008-2009, municipal level minimum wages continued to rise, especially in big eastern cities. And quite significantly for this research, the ACFTU began a big push to organize new workers and improve conditions through collective bargaining, as most clearly symbolized to the outside world by the successful unionization of Wal-Mart in 2006 (Blecher 2008; Chan 2007).

Why then, in such an environment has labor conflict continued to rise quickly? The first and most obvious answer is simply that things have not significantly improved for migrant workers, perhaps the best indication of which is the relative material deprivation of workers. Golley and Meng have found strong evidence of the deteriorating position of migrants vis-a-vis skilled urban workers: "over the 10-year period [2000-2009], therefore, we observe a significant rise in the earnings gap between the two groups, with migrant workers earning around $20 \%$ less than skilled urban workers at the beginning of the period, and 75 less at the end of the period" (2011, pp. 558-559) But the more fundamental problem is the ongoing lawless environment within enterprises that leaves workers deeply subordinated to managerial despotism and market fluctuations, and unable to secure basic contract or legal enforcement. Anecdotal evidence suggests that many employers have continually sought to evade the law, and local officials have sometimes gone so far as to publicly announce the relaxed enforcement of labor laws. ${ }^{5}$ In research I conducted in Zhejiang province, union officials went to great lengths to bargain pro-worker collective contracts at the municipal level in a number of smallcommodity goods sectors (e.g., eye glasses, wool knitwear, handbags, etc.). And yet, workers and managers in these enterprises revealed that the contracts are being completely ignored. In short, without the opportunity to organize sustainable collective power at the point of production and with local officials creating a lax regulatory environment, managers have little incentive to follow the law. Thus, despite the inclination of higher levels of the state to support prolabor legal reforms, such efforts continue to be undermined by the very same state's categorical ban on independent worker organization.

\footnotetext{
5 I have written about this in "Getting through the Hard Times Together?" [unpublished at time of this writing].
} 


\section{Reconfiguring the countermovement}

As discussed above, the seeming inclination of the Chinese central government towards class compromise has not resulted in a reduction in migrant worker insurgency, as labor remains highly commodified and labor conflicts often cannot be resolved by unions or through other legal means. This lends support to Block's reading of the countermovement as a highly contingent tendency (2003) rather than a structurally-determined pendular swing (Abolafia 1996; Silver and Arrighi 2003). I argue that countermovements against commodification must be broken down into two distinct, if dialectically intertwined, moments: the insurgent moment in which social groups marginalized in the process of capitalist development engage in relatively dis-organized and spontaneous resistance to commodification; and the institutional moment, when class compromise is established in the political and economic spheres.

I take decommodification of labor as an indicator of the emergence of the institutional moment in the economic sphere; decommodification is defined as social action that lessens the extent to which workers are immediately compelled to submit the satisfaction of their needs to the logic of the market. Things such as guaranteed health care, pensions, job security, increased wages, and having a say in how the labor process is organized all contribute to decommodification. My definition is distinct from the well-known formulation of Esping-Andersen (1990) in that I do not take potentially decommodifying national laws as indicators (since in China legal violations are endemic), but rather insist on investigating empirical conditions on the ground. The political aspect of the institutional moment is represented by incorporation of the working class. This means that workers have substantive representation both on the shopfloor (relationship to capital) and in giving the working class a voice in government (relationship to the state). If workers are able to resolve collective problems and contend with capital within rationalized, legal channels (especially collective bargaining) and if they recognize the legitimacy of their legal union representatives, this serves as evidence of incorporation. ${ }^{6}$

Decommodification and political incorporation may be mutually reinforcing trends: to the extent that workers have greater collective voice in the state and workplace, their economic standing is likely to improve; and improvements in economic standing are likely to increase the legitimacy of union representatives and collective bargaining mechanisms. In China, the state and union were for a long time largely unconcerned with the economic problem as evidenced by their presiding over the privatization of state-owned firms and labor market liberalization since the 1980 s.

But over the course of the Hu administration, certain segments of the state (notably the central government and certain provincial and even municipal governments) became increasingly interested in expanding workers' ability to consume. And the state has long been concerned with the political problem of incorporation, as they fear instability that may result from expanding labor unrest. But since the political and economic are intimately linked, some degree of decommodification will likely be necessary in order to attain incorporation. Additionally, strengthened representation in

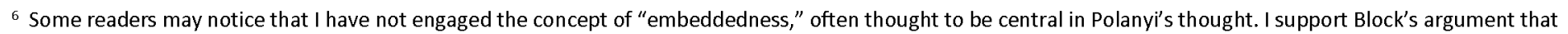

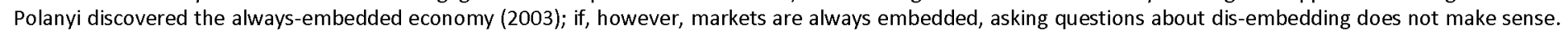

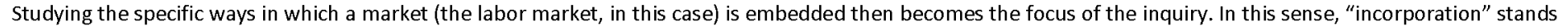

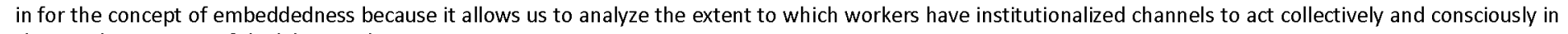
shaping the contours of the labor market.
} 
the workplace - especially mobilizational capacity-could increase the power of union representatives within the state.

A schematic of my reformulation of countermovements appears below: (Fig. 2)

In these terms, then, my question is: why is it that the countermovement in China stalled at the insurgent moment? Why have high levels of resistance among migrant workers resulted in legislative, regulatory, and symbolic ${ }^{7}$ victories but have not been translated into incorporation and decommodification? And what sorts of conditions might allow for the advancement of the institutional moment?

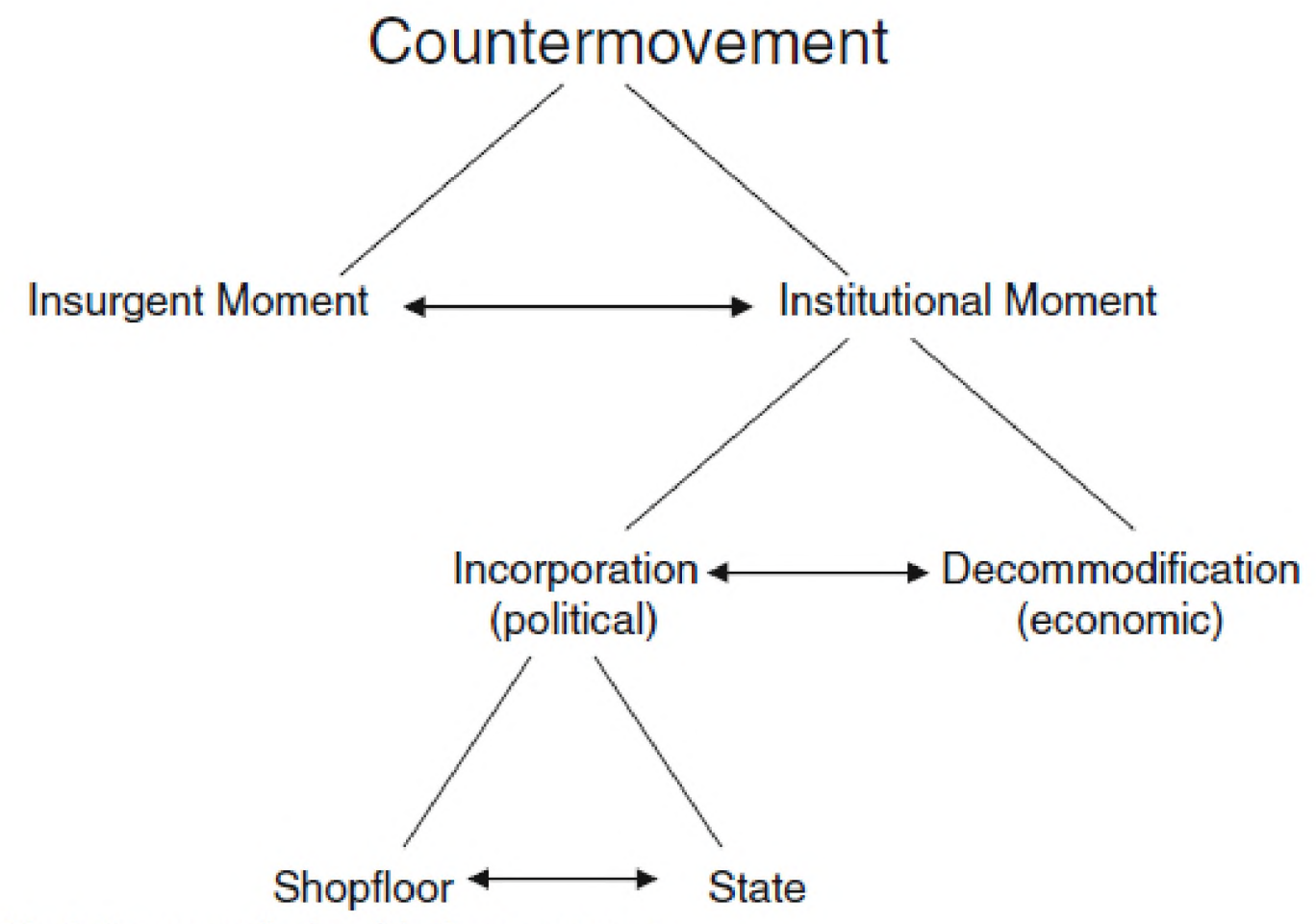

Fig. 2 Reconceptualization of the Countermovement

\section{Appropriated representation and the ACFTU}

My claim is that the transition from insurgency to the institutionalization of the countermovement (i.e., class compromise) that we would expect based on Polanyian theory has been short-circuited because the new class of migrant workers in China have emerged under conditions of appropriated representation. "Appropriated representation" is a term originally used by Weber $(1978$, p. 292) that he juxtaposed to the radically democratic "instructed representation" (ibid., p. 293), but that he did not develop at any length. I have adopted and reconfigured the term to refer to a situation in which the state unilaterally grants exclusive rights of political representation of an entire class to a particular organization in the absence of substantive or formalistic delegation from membership. Historically, unions in many other countries undergoing capitalist industrialization have played a crucial role in channeling insurgent worker energy into the construction of collective power capable of winning compromise from the state and capital

\footnotetext{
${ }^{7}$ I.e., increased rhetorical support from the state for worker grievances.
} 
(Rueschemeyer et al. 1992). But in the case at hand, the ACFTU did not mobilize or actively involve itself in the lives of migrant workers as they emerged as a new class, ${ }^{8}$ as it maintains the state's obsession with reducing labor unrest. Under conditions of appropriated representation, dispersed worker insurgency strengthens the hand of union representatives at the national level (since the state fears instability and may be willing to promote legislative reform), but simultaneously results in weak, illegitimate unions on the shopfloor that are generally incapable of enforcing laws and collective agreements.

The ACFTU

Although it played a key role in the 1925-1926 Guangdong-Hong Kong (shenggang) general strike (Kwan 1997), the ACFTU ceased to function for most of the 1930s and 1940s, and was recreated from the bottom up in 1948. Although there were at least two major attempts by ACFTU leadership for greater autonomy from the Party during the 1950s (Harper 1969; Sheehan 1998) these were both crushed. The union federation once again collapsed during the Cultural Revolution (Hearn 1977) and was then recreated by the Party in 1978, just as market reforms were getting underway.

During the 1980s and 1990s, unions did little to resist the onslaught of marketi- zation that resulted in innumerable layoffs (Solinger 2001) in the state-owned sector, as well as endemic theft of public assets and pension funds (Chen 2000). It was also at this time that migrant workers were flocking to major cities along the east coast to find employment in the private sector. Despite suffering from second-class citizen status (Solinger 1999) as well as generally brutal working conditions (Chan 2001; Choi 2003; Lee 1998) very few of these workplaces had any union organization at all. As a result, migrant workers emerged in a political context in which ACFTU- subordinate unions were almost entirely absent.

Since at least 2006, Chinese unions have been more assertive in unionizing private workplaces (especially in the foreign-owned sector) and in pushing for collective wage negotiations. However, there are a number of highly institutionalized mechanisms that ensure the union continues to draw its symbolic power from state recognition, rather than from its membership. First and most significantly, the ACFTU's subordination to the horizontally linked Party organization at every level of the hierarchy is formalized in the union federation's constitution. Union leaders from the national and regional federations are appointed by the Party and are generally not selected from within the union. By rotating in government officials from other unrelated departments, leadership is beholden to the Party rather than to their membership (which has no role in their selection). Lau has argued that union officials think of themselves and act as government officials (2003), while Chen contends that they are subject to a "double identity," trapped between workers and the state (Chen 2003b, 2009). Regardless of one's position in this debate, it is undeniable that union officials have not sided with workers against the state, and that they remain quite weak at the point of production (Clarke et al. 2004) as workers are not granted the collective right to organize (Chen 2007).

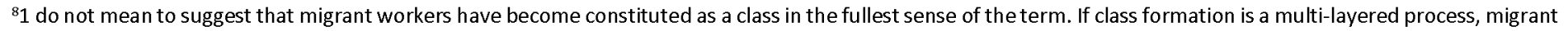
workers certainly do not engage in collective action as a class (Katznelson 1986), and thus cannot be considered a "class in reality" (Bourdieu 1985, p. 725). 
Although this relationship to the state has received more attention, heteronomy vis- a-vis capital is an equally vexing problem. Union subordination to management is ensured at the level of the firm through the system of financing. Unions are supported not by membership dues but rather by a $2 \%$ payroll tax that is paid by employers. Additionally, enterprise union chairs remain employees and are thus subject to nearly unchecked managerial retaliation. Despite a few experiments with direct elections (Howell 2008; Yu 2008) it is common practice for the enterprise union chair to be unilaterally appointed by management (the result of which is that most union chairs come from the company's human resource department).

Given these conditions, there is a strong consensus among scholars that ACFTU unions are quite weak (Metcalf and Li 2005). And indeed, I support the argument that labor is so weak on the shopfloor that it is impossible to secure basic adherence to the law. And yet, this perspective fails to account for why so much pro-labor legislation has been passed at the national level, and why pro-labor sectoral-level agreements have been reached in a number of provinces (Taylor and Li 2007). Conditions of appropriated representation allow for dispersed worker insurgency to strengthen the position of higher levels of the union in pushing for just such administrative advances, as ACFTU unions have good access to, and are recognized as legitimate worker representatives by, the Chinese state. But appropriated representation simultaneously implies the atomization of the working class at the point of production, thereby rendering these legislative advances ineffectual. And yet, we see that the dynamics of autonomous worker resistance continue to evolve, creating an ongoing dynamic between insurgency and the institutional responses of state and union.

But what does the insurgency-institutionalization dialectic look like empirically? How have the internal dynamics of the countermovement evolved in recent years in response to ongoing conflict and shifts in global economic conditions? And what are union and state responses to specific incidents of worker resistance? In answering these questions I now turn to a detailed investigation of two strikes-the Ascendant Elevator strike from 2007 and the Nanhai Honda strike of 2010. The Ascendant and Honda cases make for a good comparison. Both are capital-intensive wholly foreign- owned operations, with Ascendant located in Guangzhou and Nanhai Honda less than 25 miles away in the adjoining municipality of Foshan. Production in both factories requires skilled labor and most workers are graduates of technical schools. Regular workers enjoy somewhat better working conditions than in most labor-intensive industries in the Pearl River Delta and other export-oriented regions. And Honda and Ascendant alike employ the labor force dualism so prevalent in capital-intensive industries in China (Zhang 2008), in which a large segment of employees are hired with fewer job protections, lower wages, and worse benefits then the regular workers. And yet, we will see that different organizational capacity and labor market dynamics, as well as different overall political conditions forced the union to adopt varying responses to the respective strikes. Additionally, we will see that various levels of the union had very different responses to each strike. Data on the strikes come from 44 semi-structured interviews conducted by research assistants outside the production facilities. Research on the Ascendant case took place in early 2009, while the Honda research was conducted in the summer of 2010. Additionally, I draw on one-and-a- half years of ethnographic fieldwork (beginning in August 2008) and media reports in the discussion of broader trends in labor politics. 


\section{Commodification, resistance ... and more commodification}

Ascendant Elevator is an American owned company, which has a production site in suburban Guangzhou. Tensions in the factory began building in mid-December 2007 when the company announced to workers that they would be switching from an hourly-rate system to a piece-rate system in order to increase productivity. Workers were quite angry about the announced switch, since according to their calculations, their salary would be decreased by $60 \%$ even with increased overtime. They tried to get assistance from their enterprise-level union chair, but he was ultimately unresponsive (see below). On December 18th, 128 of the workers went on strike, completely shutting down operations at the entire production facility. Two days later, the company sent a "gentle reminder" saying that anyone who refused to sign a letter of intent accepting the piece-rate system by the following day (December 21st) would have their contract terminated at the end of the month.

Unbeknownst to the workers, enterprise level trade union chair Cheng Weiji had already discussed the new piece-rate system with management and claimed to have expressed the interests of the workers. To further grasp the farcical nature of Cheng's discussion with management, it is worth quoting at length a section of a newspaper article that appeared on December 21st:

Yesterday around 1 p.m. this reporter was finally able to see the chairman of Ascendant Elevator Company, Mr. Cheng Weiji. It was surprising to find that every one of his statements came under fierce attack from the 128 workers at the scene of the incident.

Cheng Weiji said, "Today we convened a staff and workers congress. Workers were present."

"This didn't happen," said the workers.

Cheng Weiji said, "The union contacted the representatives that you all selected to discuss the piece-rate issue."

"No, who are you saying participated?" the workers said.

Cheng Weiji said, "The night before last, the union held a meeting to discuss this issue. We informed all of the workers that there is going to be a negotiation conference today at 1:30."

"We didn't receive any notification," the workers said.

Cheng Weiji said, “Just because you didn't receive the notification does not mean that it wasn't sent. We sent it out by email."

"We don't even have computers, how can we receive something by email?" responded the workers.

In an interview with this reporter, Cheng Weiji said that the union had discussed the matter of the piece-rate system with Ascendant Elevator Company two times, and that they convened a union representative congress. The union representatives transmitted the spirit of the congress to the employees. This reporter inquired what the union was prepared to do if the company terminated the contract of employees, some of which have been at the company for 10 or more years, if they refused to sign an agreement on accepting the piece rate system. Cheng Weiji said that he is not 
an administrator, so it would not be appropriate for him to give a response. ${ }^{9}$

Clearly, the enterprise level union was not up to the task of resolving the impasse, as their representation was formalistic at best. At this point the Guangzhou Federation of Trade Unions (GZFTU) - chaired by the man generally considered the most reform- minded union leader in the country, Chen Weiguang-and the Electrical and Machine Industrial Union dispatched officers to Ascendant Elevator Company to do an investigation. As a symbolic indication of the gravity of the event, the ACFTU sent someone from Beijing to attend the investigation. The goal of the investigation was to determine if the company had gone through the appropriate legal procedures for implementing the new system, to determine if workers' legal rights were being protected, and to decide if the enterprise level union chair had fulfilled his appropriate duties. At the same time, the union began its own evaluation of the proposed changes, with the intent of coming up with an alternative piece-rate system. GZFTU chair Chen Weiguang, legal experts, and other trade union leaders planned to visit the company personally the following week to engage in negotiations.

The labor bureau also jumped into the fray. Although initially giving cautious warning to the company that their approach could violate labor laws, they quickly did an about face. Chief of the Baiyun District Labor and Social Security Bureau Xie Xijian was quoted in the newspaper as saying, "the enterprise has sovereignty over the determination of labor contracts. As long as it is above the minimum wages for the province and the city, the labor bureau cannot intervene." ${ }^{10}$ Since the bureau understood that a reduction of wages to levels below that of the legally mandated minimum was not under discussion, this comment was equivalent to removing the government from adjudication of the issue. Management's confidence in the support of the government was evident when they said that if they were unable to come to a resolution, they would "encourage" workers to file for arbitration. The pro-capital position of the state was not lost on workers, as is evidenced by this comment from a temporary worker about the strategy of workers in a second strike that took place in August 2008: "some people said we should go report it to the labor bureau, but others opposed this. Those in opposition said that when there was a conflict last time, some people went to the labor bureau, but it didn't have any effect. The labor department doesn't help workers, it protects bosses. So if you go it will be useless! $!^{11 \prime}$

After garnering much attention in the print media and on various blogs, a gag-order was implemented and the story disappeared from public discourse. It is of course significant that this gag-order was issued before the resolution of the conflict, since the likelihood of the union or other government agencies having their image tarnished was greatly reduced. However, the Ascendant Elevator incident did appear in the papers one more time at the end of the following January. Chen Weiguang, displaying some of the characteristics that have earned him a reputation as an outspoken worker advocate, publicly criticized the inaction of the enterprise level union in Ascendant Elevator: "On the surface, the Ascendant incident is a conflict between labor and capital, but in the background it magnifies the crisis of our enterprise

\footnotetext{
9 December 21, 2007. "Ascendant guangzhou company plans to take away $60 \%$ of workers salary; those who refuse to sign will be fired." Xin kuai bao.

${ }^{10}$ December 22, 2007 "GZFTU to investigate Ascendant's contract to protect the rights and interests of workers." Guangzhou ribao.

11 Interview, May 2009.
} 
level trade unions, something which is worth us contemplating." ${ }^{12}$ Chen went on to make a more general critique of these enterprise level union chairs, saying that, "some enterprise level union chairs are taking the wrong position and are completely servile towards capital. They have completely forgotten their primary responsibility as a worker representative." ${ }^{13}$ The fact that Chen's leadership and insistence that unions more effectively represent workers was unable to affect managerial authoritarianism reveals some of the fundamental weakness of the trade union.

So what was the outcome of the Ascendant Elevator incident? In interviews with workers conducted more than a year after the strike, there was universal displeasure with the results. Most of these workers participated in the strike, but said that in the end they had no choice but to sign the letter of intent. Otherwise, they said they would lose their jobs. Contrary to the promises of management and the reassurances of the union, wages for workers declined significantly after the implementation of the piece-rate system. One worker claimed that $90 \%$ of workers' salaries had declined since the strike. He said that before the strike "temp workers" such as himself earned between 2,000 and 2,500 $\mathrm{RMB}$, but that their wages had since been reduced to $1,300-1,600$. Another temp worker said that he made only 1,100 RMB the previous month. For regular workers, their original salaries had been between 4,000 and 4,500, but had since been reduced to $3,000-3,500$. While I could not verify these numbers with official documents, all interviewees confirmed that their wages had been significantly reduced.

This leads to a secondary point that was not addressed in any of the media coverage: Ascendant Elevator Company's employment of temporary workers. The implementation of labor force dualism has become increasingly common in many enterprises throughout China, ${ }^{14}$ both as a method to break employee solidarity and to maintain greater flexibility in human resource management. This was the case in the Ascendant factory, with a very significant number of employees hired as "temp workers" through a hiring agency. The long-term maintenance of this sort of labor regime is in violation of the legal requirement of "equal pay for equal work." Indeed, interviewees from Ascendant Elevator expressed that as temp workers they did exactly the same work as regular workers but were compensated at a much lower level. This system was not addressed at all in the negotiations at the end of 2007. The failure to address this issue is significant, because temp workers went on strike briefly in August of 2008, protesting low wages and unequal treatment. I was unable to get more detailed data on this event, but two workers mentioned it in interviews.

Finally, there is little evidence that the union did anything to secure increased recognition from workers. Many interviewees, despite participating in the strike, were unaware that the factory had a union:

Interviewer: Before the strike, what actions did the Ascendant company union chair take?

Respondent: I didn't know our company had a union!

\footnotetext{
12 January 1, 2008. "Some union chairs are taking the wrong position." Guangzhou ribao.

13 Ibid.

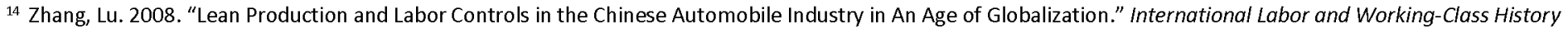

73 , pp. 1-21.
} 
Interviewer: Well then, how about the higher level trade union?

Respondent: Higher level trade union? Is that the labor bureau? ${ }^{15}$

In response to the same question about the behavior of the union chair, a different respondent said, "my friend said that the union chair and the boss 'wear the same pants,' he just speaks for the boss!"16 This respondent said that the union chair eventually told them that management's actions were legal and that they would either have to obey the new rules or leave the company.

But perhaps the most succinct summary of the outcome of the Ascendant Elevator case came from a temp worker who had this to say when asked if he agreed with the assessment of GZFTU leadership that there was a "winwin" resolution to the strike: "Where is there win-win? It was an absolute and thorough defeat for the workers. An absolute defeat!"17

\section{The Honda conflagration}

Honda's production chain in China consists of a somewhat convoluted system of ownership. The most significant company is Guangzhou Honda, a 50-50 joint venture with the state-owned Guangzhou Automobile Group Corporation, where a majority of units are produced. Additional assembly plants include Honda Automobile (China), which produces for foreign markets, and the joint-venture Dongfeng Honda located in Wuhan. These assembly plants are served by a variety of parts manufacturers, including the wholly Japanese-owned Nanhai Honda. Starting production in March of 2007 with an initial investment of USD $\$ 98$ million, ${ }^{18}$ the company was Honda's fourth integrated automatic transmission production plant in the world. ${ }^{19}$ Aside from producing transmissions, the plant also makes drive shafts and connecting rods for engines. ${ }^{20}$ In part because Honda believed that work stoppages were highly unlikely in authoritarian China, the Nanhai plant was established as the sole supplier of several key parts for the entire China operation. In part because of the key position that auto manufacturing plays in the economy, the government put a high premium on maintaining good labor relations in this sector. As a result, all the Honda assembly and parts manufacturing plants in Guangdong had unions established.

Although workers at Nanhai had long been unhappy with the low wages and had discussed going on strike, hardly anybody knew that Tan Guocheng was going to initiate the strike when he did. ${ }^{21}$ On the morning of May 17 th, just as production normally began at 7:50 a.m., Tan hit the emergency stop button and both production lines in the assembly department were shut down. For most of the plant's nearly 2,000 workers, this was to be the first they heard of the strike. Even one worker who was from the assembly department and had heard discussion about the possibility of the strike was caught unaware: “I didn't know the strike was going to happen.... I wasn't there at the time [because I

\footnotetext{
15 Interview, May 2009.

16 Interview, May 2009.

17 Interview, May 2009.

18 June 11, 2010. "dongfeng bentian: wufa duoshan de hudie xiaoying" [Dongfeng Honda: No way to hide from the butterfly effect] E'shang zazhi

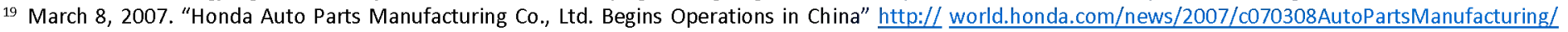
[accessed July 3, 2010].

20 Ibid.

21 This is a pseudonym. The same person also appeared as "Tan Zhiqing" in other reports.
} 
went to the bathroom]. When I was finished in the bathroom I came out and there weren't any people. I stood there looking, 'huh, how come they aren't at work?'"22 Even if workers in other departments were not involved in the planning, given the critical position of the assembly department in the production process, other departments were forced to shut down in a matter of hours. By that afternoon, management had set up suggestion boxes and pleaded with the workers to resume production, promising them that they would consider their demand for higher wages and provide a full response in 4 days. Perhaps because of their relatively small numbers, the strikers took management at their word and production was resumed that very day.

Workers formulated an initial demand of an RMB 800 wage hike (an increase of nearly $50 \%$ for regular workers), but during the series of negotiations that began on the 20th, the enterprise union alternated between passivity and hostility. Workers complained that during the bargaining sessions the union representative did not say anything at all, but merely observed the proceedings. When the strike initially began on May 17th, a team of investigators from the district labor department and trade union were dispatched to the factory. Leaving no doubt which side of the struggle they were on, the officials announced, "according to relevant regulations, we did not find that the factory is violating the law." ${ }^{23}$ One worker who was selected as a representative was quite disappointed with the behavior of the enterprise union chair, Wu Youhe, in the first round of negotiations:

[The enterprise union chair] invited a lawyer [to the first round of negotiations]. The lawyer said that our strike was illegal. He [the union chair] didn't have any views of his own, and couldn't make any decisions. He always asked the general manager what to do. At bottom he is a chairman, and isn't controlled by the company, he has this power. But for him, everything had to go through the general manager, and he would help the general manager refute the things we said." 24

With the workers back on strike, worker representatives were convinced to come back to the table on the 24th. Still trying to serve as an intermediary, the union chair attempted to persuade the workers to accept management's offer of an RMB 55 increase in food subsidies - a far cry from the RMB 800 they were demanding. This ineffectiveness was not lost on the workers, with one striker commenting, "The union said it stood for our interests. They said us employees could give them any demands and they would pass them on to management, and they would resolve things for us. But they didn't do this in the slightest." 25

The strikers refused management's offer on the 24th, and the situation escalated on the 25th when all of Honda's assembly plants in China were completely shut down due to lack of parts. Although management increased their offer, ${ }^{26}$ workers were determined and the strike continued. At this point workers had already formalized their demands, and in addition to the primary demand of increasing wages by RMB 800, they also demanded that two fired workers be re-hired, that there would be no retaliation against strikers, and that the enterprise union be "re-organized".

\footnotetext{
22 Interview July, 2010.

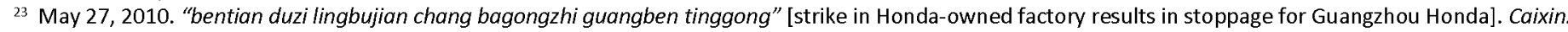

24 Interview, July 18, 2010.

25 Interview, July 2010.

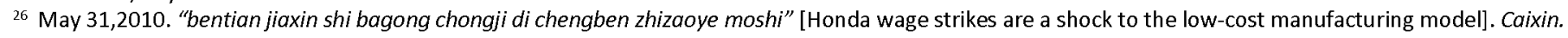


According to some strikers, the demand for union re-organization emerged after seeing that the union had failed to represent them actively in the previous negotiations sessions. Despite the mounting economic and political costs, the events of May 31st took everyone by surprise.

The union as strikebreaker

On the morning of May 31st a large contingent of vans and buses pulled up to the front of the factory. The vehicles were filled with approximately 100 men, all of whom were wearing yellow hats and badges reading "Shishan Township Federation of Trade Unions," the immediately superordinate union federation. Having just left a meeting with management, some workers from the assembly department moved to return to the area in front of the factory where they had been demonstrating over the previous nearly 2 weeks and a confrontation with the union group emerged. As confirmed from multiple independent sources, the union people began filming the workers and demanded that they return to the factory and end the strike. A tense situation quickly escalated and soon devolved into a physical confrontation during which several workers were struck by people from the union. This infuriated the workers, and a strike that seemed to be losing steam was quickly re-invigorated. Another physical confrontation occurred and this time the union side was even more violent than before, with several workers suffering light wounds. The aggressors quickly retreated to their vehicles and refused to come out.

At this point, the government decided things had gone too far, and took steps to settle the conflict. Riot police were deployed, though they never engaged the workers. The authorities additionally cordoned off the road into the factory and nobody was allowed entrance. Whichever government agencies had supported the peaceful strike were not interested in more violent confrontations or the possibility of the strikers leaving the production grounds.

It is certain that most of the strikebreakers were not actually union officers. The first thing mentioned by many workers is that it seemed preposterous that the township level federation, with only a few paid members on staff, could recruit so many officers from other union branches. One worker involved in the scuffle said that some of the strikebreakers (all of whom were male) had earrings and tattoos, items that union officials would be very unlikely to sport. But if most of the thugs were not actually union officers, it is simultaneously undeniable that the district union federation had a hand in organizing the strikebreakers, a point made obvious in a letter they wrote to workers (see below). A foreman from the assembly department was blunt in his assessment: "of course it was the union's idea. Who else would have such a stupid idea? Only Chinese unions would think of this." ${ }^{27}$ It is, however, unclear to what extent the union federation was acting at the behest of management or whether they were taking independent action.

When workers received an open letter from the Shishan Township and Nanhai District Federations of Trade Unions the following day, the local union leadership provided a tepid apology and did not denounce the violence that had occurred the previous day nor did they attempt to deny that they had organized the strikebreakers. The letter is worth quoting from at some length:

27 Interview, September 29, 2010. 
A portion of these employees, after receiving word of the incident, seem to have misinterpreted the actions of the union as siding with management. Yesterday's incident came entirely as a shock to us. If people feel that some of the methods used in yesterday's incident were a bit difficult to accept, we apologize.

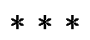

The behavior of the above mentioned group of 40 or so workers has already damaged the interests of the majority of employees. In addition, such behavior harms factory production. The fact that the union has stood up and admonished these workers is entirely in the interests of the majority of employees. This is the responsibility of the union!

It would be unwise for workers to behave in ways that go against the interests of themselves and others because of impulsive emotions. Some employees are worried that representatives who are willing to stand up and enter into talks with management would later receive the reprisals of management. This is a misunderstanding. ${ }^{28}$

The letter went on to criticize workers for refusing to accept management's previous offers. The letter concluded, "Please trust the union. Trust each level of Party officials and government. We will definitely uphold justice."29

The letter from the Shishan and Nanhai union federations was unsatisfactory to the strikers. As one worker activist put it, "Their apology letter wasn't an apology letter at all, so we were pretty enraged." ${ }^{30}$ An open letter from worker representatives that appeared 2 days after the union's apology letter was defiant: "The union should protect the collective rights and interests of workers and lead the workers in the strike. But up until now, they have been looking for excuses for the union people's violence against striking workers, and we seriously condemn this." ${ }^{31}$ Additionally, the letter went on to express "extreme rage" at the union's claim that it was their hard work that had caused management to increase their offer of wage increases, arguing rather that these were, "won by the blood and sweat of striking workers facing extreme pressure." ${ }^{32}$ Relations between the strikers and the township level union could not have been worse, and certainly heightened the tension of the unfolding drama.

\section{Resolution}

If the tactics of the township level union failed to break the deadlock, higher levels of the union and Party were much more sympathetic to the strikers. I heard from GZFTU leadership that Guangdong Party secretary Wang Yang supported the strike and the workers' wages demands, and that there was even support in the central government. The Central Propaganda Department did not issue a reporting ban until May 29th, nearly 2 weeks into the confrontation, at

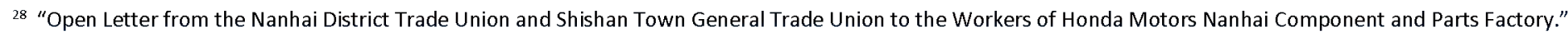

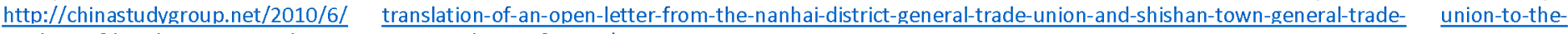
workers-of-honda-motors-nanhai-component-and-parts-factorv/

29 Ibid.

30 Interview, July 18, 2010.

31 The open letter from the worker representatives was posted online, available at: http://zggr.cn/?action- viewnews-itemid-9411

32 Ibid.
} 
which point the strike wave had spread to other factories. ${ }^{33}$ This was an indication that the central government was willing to allow more pressure to build on management, as it is rare for coverage of strikes to go on for so long. Guangdong Federation of Trade Unions (GDFTU) vice-chair Kong Xianghong took an active role in the negotiations and was supportive of the wage demands.

To find an orderly resolution, the various government agencies that had become involved in the strike demanded that the workers select representatives. Although there had been a hastily arranged set of negotiators selected in the first round of talks, strikers had become reluctant to produce representatives, particularly after the two people who initiated the strike were fired. This unwillingness to negotiate presented a problem for the state, and they brought in Guangzhou Automotive CEO and National People's Congress delegate Zeng Qinghong to speak with the workers. Zeng convinced the strikers to select representatives and to begin a conditional resumption of production late on June 1st. On June 4th, a well-known labor scholar from Beijing joined the worker representatives as their legal counsel. Negotiations eventually produced an agreement in which regular workers received a wage hike of approximately RMB 500, while the "interns" (students sent to the factory from technical schools who receive wages significantly below those of regular workers) got RMB 600, an increase of more than $70 \%$. Such large wage increases in response to strikes were unprecedented in China.

\section{Strike wave}

Before discussing the political fallout from the Nanhai strike, it is important to note that the ongoing coverage of the struggle had sparked widespread resistance among industrial workers around the country. The central government had given the okay for media coverage to continue, as it fit in with their inclination towards raising wages for skilled workers. Additionally, the fact that Honda is a Japanese owned factory was important, as it appeared possible to divert anger about worker mistreatment in nationalistic, rather than class-based, directions. ${ }^{34}$ And yet, the central government certainly got more than it was bargaining for as strikes ripped through the auto industry, even spilling over into other sectors. While many strikes targeted Japanese-owned factories, this was certainly not true in all cases. With workers experiencing generalized dissatisfaction, a small relaxing of media controls was all it took to ignite an outbreak of intensified insurgency. It is important to keep this uptick in class struggle in mind to understand the context in which both the Nanhai and subsequent strikes were resolved.

In each strike, the primary demand was for large wage increases. While demands related to union reorganization were not as prevalent in other cases, they did appear in many strikes. Perhaps most noteworthy among the copycat strikes was that initiated on June 21st at Denso in the Nansha district of Guangzhou. Employing 1,100 workers, the Japanese-owned Denso is a major auto parts supplier, in particular for the Toyota assembly plant located in Guangdong. On several occasions, workers in the plant had brought up issues related to pay and living conditions with

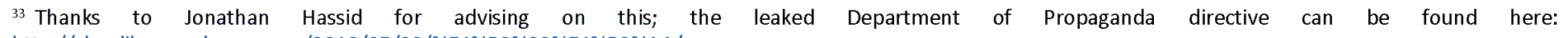
http://zhenlibu.wordpress.com/2010/05/29/\%E4\%B8\%89\%E4\%B8\%AA/

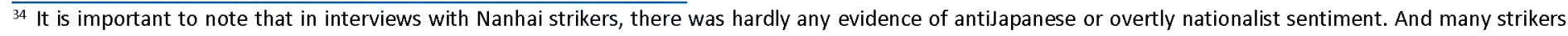
expressed great opprobrium for their Chinese managers.
} 
the enterprise union, but nothing changed. Indeed, a shop-floor union representative admitted that the "small group" (xiaozu) meetings that are supposed to happen once a month had only been held once ever, and that there had never been an employee congress (meeting for all enterprise employees). ${ }^{35}$ Just as had been the case at Nanhai, stagnating wages and the inability/unwillingness of the union or management to take worker grievances seriously were the impetus for the strike. Although they were clearly following the lead of the Nanhai workers, one Denso employee said, "we wanted to go on strike for a long time." 36

The most significant thing about the Denso strike was the militant and tightly organized nature of the strike. During the weekend before the 21st, a group of up to 200 workers gathered in secret to discuss plans. At this meeting, the "three nos" strategy was decided upon by workers. The three nos required that for 3 days there would be no work, no representatives, and no demands. Workers knew that within 3 days lack of parts would cause a shutdown in the neighboring Toyota assembly plant. Additionally they had strong reason to believe that representatives would face retaliation or co-optation. By waiting 3 days before issuing any demands, they would be bargaining from a position of great power, as they anticipated that losses would be mounting not just for Denso, but for the entire Toyota supply chain.

Their calculation was correct. They started the strike on the morning of the 21 st, and workers blocked trucks from leaving the plant. By that afternoon, six of the other parts plants in the "auto city" industrial zone where Denso was located were also shut down. The following day, the nearby Toyota assembly plant closed for lack of parts. ${ }^{37}$ And on the third day, workers elected 27 representatives and went into negotiations. Their central demand was simply a wage increase of RMB 800. The negotiations were attended by worker representatives, the CEO of Denso (who had flown in from Japan), officials from various levels of the union, as well as Zeng Qinghong (the general manager of Guangzhou Automotive and National People's Congress delegate who had played a key role in resolving the Nanhai strike). Following the negotiations, management and Zeng pleaded with the workers to return to work and promised them a resolution by the 25 th. Worker solidarity broke down somewhat at this point as many began to return to work, although output on the 24th was far below usual levels. And on the morning of the 25th it was announced that they would be granted an RMB 800 wage increase.

The evolving political position of the union was evident in the Denso strike, which took place within the jurisdiction of Chen Weiguang's GZFTU. When the workers first went on strike, they rejected the intervention of the higher levels of the trade union, likely with the Nanhai incident fresh in their minds. But under the leadership of Chaiman Chen, the union proclaimed that it would not play a "mediator" role as requested by the government, but that it would represent the workers' interests and only the workers' interests (rather than the typical rhetoric about win-win outcomes). Additionally, and quite significantly, the local public security bureau told the union they wanted to speak

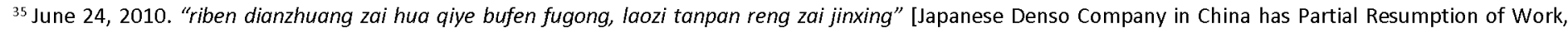
Negotiations Continue]. Reuters.

36 Ibid.

37 Ibid.
} 
with worker representatives, but the union refused to comply.

Workers struck in another nearby Honda supplier, again severely disrupting production. At the Guli Lock Factory in Zhongshan, workers marched in public and blocked roads. As early as May 28th, Hyundai Automobile workers walked off the job. And an absolutely massive strike wave engulfed a development zone in the northern city of Dalian. From the end of May through August, 70,000 workers in a variety of sectors went on strike, affecting 73 enterprises in the zone. As reported by union officials, workers won an average wage increase of $34.5 \% .^{38}$ This was the third time the Dalian development zone had experienced a strike wave since 1994. Some Japanese companies that had not experienced strikes decided to give their workers a preemptive raise, with National increasing wages by RMB 500 and Panasonic 200$300 .^{39}$

It is not clear how many workers went on strike in the summer of 2010 , but it is certain that the dozens of reported cases are merely a small portion. Around the country, workers were granted unprecedented wage increases. In the fallout from the strike wave, union officials and media commentators declared the end of low wage labor in China.

\section{Response to the 2010 strike wave}

In the wake of Nanhai and other strikes, the public position of many union officials, particularly in Guangdong, began to change. Chen Weiguang, always somewhat more daring than his other union colleagues, publicly stated that the strikes had been a force for encouraging trade union reform and that it was allowing labor negotiation systems to become more mature. ${ }^{40} \mathrm{He}$ additionally expressed concern that unions had continued to be passive and that they were "tailing" workers, publicly stating that unions could not "hide forever." ${ }^{41}$ In October, the GZFTU issued the "Advice on Strengthening Union Work and Developing the Organizational Function of the Union," which emphasized that in the course of resolving labor conflicts, "the union must be clear on its role, that it cannot be a mediator but rather only represent the side of workers. ${ }^{\prime 2}$ Kong Xianghong was quite explicit in his criticism for the lower levels of the union, as indicated by the following statement: “... the union must not be antagonistic to striking workers, but the local unions were precisely standing in an antagonistic position. So the workers said that they want to disband the union, that the union is a running dog and a traitor. ${ }^{143}$ While hardly a radical position, Kong's solution to the problem indicated a remarkable divergence from earlier positions held by most union officials: "I think that controllable strikes are a right which should be enjoyed in order to govern a stable and harmonious society. What is harmony? Harmony is admitting conflicts and integrating the conflicts into a systematized path for resolution. Many of us Party cadres are lacking precisely the correct recognition of this problem." ${ }^{44}$ Even GDFTU chair Deng Weilong, not known for his progressive

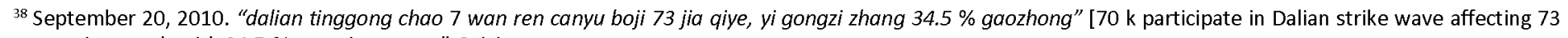
enterprises, ends with $34.5 \%$ wage increases." Caixin.

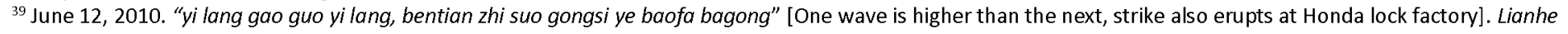
Zaobao.

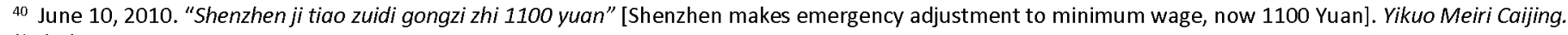

${ }^{41}$ Ibid.

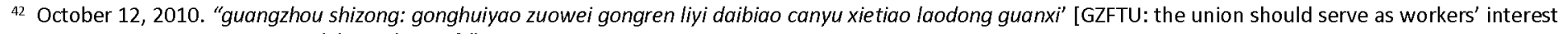
representative in participating in labor relations]."

${ }^{43}$ June 22, 2010. "kekong de bagong shi hexie de yingyou zhi yi" [Controllable strikes are a right that should be enjoyed for harmony]. Zhongguo Qiyejia.

44 Ibid.
} 
politics, admitted that very few enterprise-level union chairs in Guangdong are democratically elected. Deng went on to say that one consequence of this is that, "in the eyes of many workers, unions are an organization subordinate to the boss . when labor conflicts become acute, unions represent the interests of the boss." ${ }^{45}$ The position of ACFTU leadership was considerably more conservative, as they mostly repeated old exhortations to increase unionization in private enterprises. However they did issue a new specific call for increasing the wages of production workers.

In some ways, the central Party leadership was ahead of the ACFTU in their position. Zeng Qinghong-the former Politburo Standing Committee member and vice-president of China, not the Guangzhou Automotive CEO-wrote a long statement on the value and necessity of expanding and strengthening collective bargaining. While he stopped short of calling for the legalization of strikes, his argument implied that having a credible strike threat could help in rationalizing labor relations:

In other countries, the strike is only the last resort and frequently is used as a threat; domestically, employees strike first and then negotiate. That is to say, they use strikes and other extreme measures to win the right to negotiate. First, the production line stops, and then they consider how to resolve the problem. This sort of pre-emptive coercive approach expends a large volume of social resources, giving workers a high cost to protect their rights, employers a high operating cost, and the government high costs in protecting stability. This constitutes an unfortunate lose-lose situation. ${ }^{46}$

Zeng is referring in quite precise terms to the costs that worker insurgency exacts on accumulation-a situation that, as he argued, requires an institutional response in the form of substantive collective bargaining. Staking out a more reform-oriented position, the other Zeng Qinghong (writing in his capacity as a National People's Congress delegate) said in a published article that in the process of resolving the Honda strikes he, "deeply felt the necessity of legislating rights for economic strikes. ${ }^{47}$ Although the Party did not immediately embrace his call for national- level legislation, the topic was no longer taboo.

The moment, it seemed, was ripe for an institutional re-alignment. In pursuit of a stabilization of labor relations, the Guangdong provincial government re-issued a proposed set of laws entitled, "Regulations of Democratic Enterprise Management," which had been considered in 2008 but put aside when the economic crisis deepened that fall. The regulations included an article that allowed for collective bargaining if $1 / 5$ of enterprise employees demanded it. Once such a decision was made, employees could democratically elect their negotiating team, albeit under the supervision of the enterprise or regional trade union. Once the request for collective bargaining was submitted to the employer, bargaining had to begin within 15 days. In addition to these seemingly pro-labor provisions, the law also explicitly forbade workers from engaging in strikes or slowdowns while negotiations were taking place. However, as the government was seeking public opinions on the draft regulations, they encountered stiff resistance from the Hong Kong

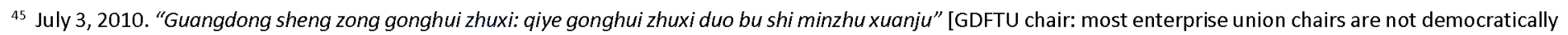
elected]. Yangcheng Wanbao.

46 http://auto.xinmin.cn/rolLnews/2011/03/07/9639022.html (accessed March 10, 2011)

47 http://auto.xinmin.cn/rollnews/2011/03/07/9638257.html (accessed March 10, 2011)
} 
General Chamber of Commerce. Before the regulations could be passed into law, it was once again shelved, although union officials claimed it was out of concern for disrupting the Asian Games being held in Guangzhou in November, rather than because of pressure from employers. In October of that year, Chen Weiguang said that this was just a minor hiccup and that the regulations would certainly be passed in the future (though at the time of writing, that was yet to occur).

Even if voices calling for reform were gaining the upper hand, it is important to note important limitations. While Chen Weiguang argued that strikes could be legalized, he consistently affirmed his opposition to "political" strikes. Even for relatively pro-labor trade unionists such as Chen, the discourse of accepting the "reasonable demands" of workers continued to hold sway. "Reasonable" is meant to imply that worker demands cannot go beyond immediate workplace issues, and that the authorities retain the paternalistic authority to determine what constitutes reasonableness even among strictly economic demands. Additionally, trade unionists by and large maintained the obsession with "stability maintenance" that characterized all government agencies during this period. In September of 2010, a conference was held in the Luogang district of Guangzhou that in part focused on how unions can effectively respond to strikes. Following the conference, the district union published a book summarizing the experiences of various enterprise unions where they argued:

... when handling spontaneous mass incidents, enterprise level unions definitely must objectively analyze and recognize the cause and substance of the mass incident. When the conflict is just sprouting they must quickly communicate with the relevant government departments, and quickly devise a strategy to contain the incident from expanding and intensifying. ${ }^{48}$

Even if collective bargaining was coming to be embraced by more unionists, it seemed likely that most enterprise unions would continue to be reactive to strikes.

\section{One year later-assessing the outcomes}

But if major political changes were beginning at the provincial and even the national level, what happened at Nanhai Honda in the months following the strike? Of particular importance is whether the promised wage increase actually materialized, whether union elections took place and collective bargaining mechanisms established, and what workers' perceptions were of subsequent changes. Although there are continual reasons for pessimism, some important changes did in fact take place at Nanhai.

The announced wage increases of approximately RMB 500 for regular workers and RMB 600 for interns did in fact materialize, thereby distinguishing this case from many others. But few workers were satisfied with the settlement, feeling that their wages were still too low. And with the possible exception of union re-organization (see below), the other $100+$ demands put forth by workers had seemingly been brushed aside, something that was quite clear in this comment from one worker:

\footnotetext{
${ }^{48}$ P. 91, 2010. Jiyuyu tiaozhan: gonghui gongzuo 100 /i [Opportunity and Challenge: 100 cases of union work]. Guangzhou: Guangzhou shi luogang qu zong gonghui.
} 
Actually, I'm not satisfied with the results of the strike. We also demanded an hour for our lunch break, and they didn't agree to this. And us women wanted a day of rest for when we're menstruating, but they didn't agree to this. Menstruating is so uncomfortable for girls, and they wouldn't agree to even 1 day..$^{49}$

It is thus apparent that even if management was willing to accede to some wage demands, other workplace issues continued to be ignored.

Even during the strike, some worker activists had been aware of the pressing need to build collective power, with some claiming that this was even more important than wage increases. While such a politicized point of view was not generalized among the workers, it was certainly an important current, particularly amongst the leaders. Although there were no open calls for an independent union during the course of the strike, it is of utmost importance to recognize that this was something that had been under discussion amongst the organizers:

Worker A: I think the union issue is more important than raising wages now. Actually, at the time we considered a huge issue, whether to establish China's first union. A democratic union.

Worker B: If it really happened, we'd be quite proud.

Worker A: Really proud. When we wrote that open letter, we discussed establishing the first one in China ... there isn't anyone that really does things for us, and other unions of course are the same, or even worse. So we wanted to take the union . because at the end of the day, the union is the representative of workers. ${ }^{50}$

That workers did not end up calling for an independent union is of course due to their recognition that this would certainly be met with harsh repression. A less contentious framing was to call for union "re-organization," which entailed holding new elections for enterprise-level officers while remaining within the structure of the ACFTU.

What then was the outcome with regard to the demand for union re-organization? Vice-chair of the provincial federation Kong Xianghong took up responsibility for responding to the Nanhai strikers' demand for new union elections. Indicating consultation with the central government, Kong announced shortly after returning from Beijing that a democratic election would in fact be held in Nanhai, though it was notably only announced in the Hong Kong media. ${ }^{51}$ In an unprecedented move, union leadership said that they would allow students and researchers from Sun Yat- sen University to observe the election proceedings. However, there was some subsequent backtracking. Rather than allow for workers to immediately hold a general election to replace the discredited enterprise chair Wu Youhe, elections were only held for team (ban) representatives - the lowest level of the enterprise hierarchy. In each of the 30-40 person teams, there were relatively democratic elections, although interns were not allowed to run. While it is unclear if management or government intimidation occurred, many were surprised that Li Xiaojuan, one of the lead organizers and negotiators who was the sole signatory of the bargaining team's open letter, was not elected team representative.

\footnotetext{
49 Interview, July 4, 2010.

50 Interview, July 18, 2010.

51 June 14, 2010. "nanhai bentian ni minxuan gonghui zhuxi" [Plans for Nanhai Honda to hold democratic elections for union chair]. Ta Kung Pao.
} 
From the perspective of most workers, there was not any significant change in the union following the strike. More than a month after the strike concluded (but before the team-level elections took place), one worker expressed continual dissatisfaction with the enterprise union:

If you're an employee it's impossible for you to be heard by the higher ups. It's doesn't matter who you talk to, it won't work because you can't get in a word with the office [management]. The union doesn't come down to the shopfloor at all, they just collect the dues and whatever, or organize one outing a year. To be honest, I don't know even a couple people from the union. It was just that when we first came, there was a woman and she said she was from the union. So they just collect the dues each month and that's it. ${ }^{52}$

When a different worker who had been at the plant since 2008 was asked whether he would participate in elections for union representatives, he said, "no, I won't, because the union is just those government people, it's just for the managers." ${ }^{53}$ More alarming, even after being elected as a union representative (at the team level), one worker continued to be dismissive about the promise of union re-organization:

Anyway, they have this idea, but ... the union is useless. Go ahead and change [the union officers], but I'm indifferent to whether they change or not. If they change or not, there isn't any use .... I think they can't help me with anything .... So if this company has a union or not, it makes no difference. ${ }^{54}$

This representative even said that the union was unnecessary for collective bargaining and that having a union, "is just another expense." ${ }^{55}$ But the difficult position of the workers vis-a-vis the union was revealed by one worker's frustration when asked if he still trusted the provincial union federation: “we have to trust them, even if we don't trust them we have to trust them. Who else is there to trust now? Nobody." ${ }^{\prime 56}$

If workers remained suspicious or indifferent towards the union, by late winter 2011, it was clear that power relations at Nanhai Honda had shifted in the wake of the strike. Starting in February, the enterprise union, working with the direct supervision of Kong Xianghong from the provincial union federation, entered into collective wage negotiations with management. The democratically elected team-level representatives were able to take part and their initial wage demand was for a monthly wage increase of RMB 800 . In three rounds of negotiations that appeared not terribly dissimilar from similar processes in liberal democracies, offers and counter-offers were exchanged. Both because of the intervention of the provincial union federation and an awareness of the possibility of workers to mobilize independently, management bargained in good faith. In the end, the union got management to increase their initial offer quite significantly, and workers won a monthly increase of RMB $611 .{ }^{57}$ It appeared as if a real system of collective bargainingone in which actual bargaining takes place-was beginning to take shape.

\footnotetext{
52 Interview, July 13, 2010.

53 Interview, July, 2010.

54 Interview, September 29, 2010.

55 Ibid.

56 Interview, July 18, 2010.

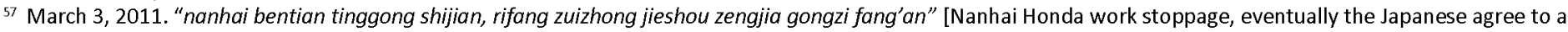
wage increase]. Nanfang Ribao.
} 
This seeming breakthrough must of course be qualified with many significant provisos. The first is that wages at Nanhai were very low when compared to the joint- venture assembly plants. Strikers had specifically cited the much higher wages at Guangzhou Honda as a reason for their actions, and post-strike their wages remained lower than those at the joint-venture. Second, the structural power of workers at Nanhai is much better than workers in either the service industry or other manufacturing sectors. Perhaps only workers in transportation or energy exercise a comparable capacity to inflict damage on the economy by withholding their labor. A third and directly related point is that the wage increases coming from the strike resolution and from the winter 2011 round of collective bargaining were presided over by the provincial authorities. In less critical industries and in less economically developed regions of the country, the likelihood that workers would have backing from provincial authorities is slim. And finally, it is worth emphasizing again that non-wage issues were completely unaddressed in the subsequent round of collective bargaining. Following the second wage raise, Kong Xianghong proclaimed that, "collective wage negotiations at Nanhai Honda will become a classic case of Chinese unions for MBAs." 58 Perhaps this is so; but its replicability is dubious.

\section{Insurgency and institutionalization}

What does the comparison between Ascendant Elevator and Nanhai Honda tell us about the relations among insurgency, decommodification and incorporation, and development? Why did strikes in similar factories in neighboring cities produce dramatically different results? And what are the implications for theory?

To review briefly, the strike at Ascendant was, in the view of one of the participants, an "absolute and thorough" failure. Worker sentiment aside, the implementation of a piece-rate system deepens commodification of labor. Management argued that a piece-rate system needed to be implemented because fierce competition in the industry required that they increase productivity. Piece-rates are a key strategy of capital to shift risk onto individualized workers and to dissolve potential bases of solidarity, and in this sense increases the submission of needs satisfaction to the logic of the market. Additionally, the dramatic decrease in wages that workers experienced means that they have fewer financial resources at their disposal to satisfy their needs. And finally, the union, capital, and the state combined forces to reject any worker participation in the determination of the labor process. In short, while workers rebelled against increased commodification, state, union, and capital allied in repressing this mini-countermovement. The commodity character of labor was not only maintained but enhanced. Unsurprisingly, a second attempted strike took place less than a year later. It is clear enough that unions were unable to play a role in decommodification of labor, even in response to outbreaks of insurgency.

In Nanhai and other workplaces that were affected in the 2010 strike wave, the results were quite different. Workers at Nanhai won a wage increase in June of 2010, and gained an even larger wage hike (in absolute terms) without striking in the winter of 2011. Of course, two worker activists were fired without the union protesting, indicating continuing managerial authoritarianism. There was no agreement to transfer temp workers into regular workers, implying ongoing precarity for a huge portion of the workforce, as well as compromised social protection (since these 
workers do not receive social insurance). Demands related to workplace issues continue to be ignored by union and management alike, indicating that there have not been improvements in labor process control. Thus, from an economic standpoint, workers in Nanhai were able to make gains in wages while other indicators of decommodification remained essentially unchanged.

When we look at indicators of the political incorporation of workers into the union, we see some important differences as well. At Ascendant, GZFTU and ACFTU officials intervened to try to broker a resolution to the strike. But there was no attempt made to re-organize the union or to build a sustainable organization capable of bargaining with capital. As soon as union higher ups moved on, management reneged on the deal, and workers were subject to the very enhanced commodification that they had originally resisted. In this case, the union was acting merely to ameliorate the immediate crisis of suspended production; as soon as that issue was resolved, they returned to passive repression, which allowed managerial authority to continue unabated. Workers continue to hold the union in contempt, and are unlikely to be able to resolve future grievances through the enterprise-level union organization.

Nanhai represents a somewhat different outcome in this regard. It is true that regular workers continue to think that the union is useless, and that even some elected representatives are highly doubtful of its capacity to bring about important change. That being said, a number of team-level representatives were elected, and subsequently were allowed to partake in collective wage negotiations. While I have already discussed the many conditions that make Nanhai exceptional, these negotiations produced a very significant wage increase for workers. Although it is unclear what will happen with the Nanhai enterprise union once the provincial union federation withdraws from direct supervision, a precedent for continual rationalized modes of contention has nonetheless been established. Depending on the specifics of how collective bargaining takes place (e.g., are rank and file involved in formulating demands, mobilized during contract fights, kept in regular contact with leadership, able to ratify contracts democratically, etc.?), this may increase worker identification with the union. In the aftermath of the strike, it did not appear that workers had any greater interactions with the union or hopes that it could improve things for them in the future. Even when the provincial unions preside over substantial wage increases, such actions may be insufficient to result in the political outcome of worker incorporation. This suggests that appropriated representation may be a greater obstacle to political incorporation than it is to decommodification.

When trying to explain the different outcomes in these two incidents of worker insurgency, one could refer to the differences between elevator and auto parts manufacturing. Certainly, elevator production is not as crucial a feature of the economy as is auto, and the construction industry does not depend on justin-time manufacturing (as is the case in the auto sector). That being said, with real estate speculation coming to be a key element in economic growth in China (Hsing 2009), elevators are hardly unimportant. Because of the structure of the supply chain, the stoppage at Nanhai had immediate effects for a number of other plants, something that was not true in the same way at Ascendant. And Ascendant workers started with wages considerably higher than those of the Nanhai workers.

Without discounting the differences between auto parts and elevator manufacturing, I argue that these 
differences cannot account for the divergent outcomes between our two cases. Rather, between late 2007 and early 2010, two inter-related related currents-one political and one economic-led the provincial and central authorities to take a very different approach in responding to worker insurgency. On the political level, 2008 and 2009 saw unprecedented levels of labor conflict (with the Pearl River Delta as the epicenter), in which labor arbitration courts were completely overloaded and worker insurgency frequently spilled out into the streets. Economically, the onset of crisis increased the central government's determination to shift away from a model of development so wedded to exports. And in Guangdong, the provincial authorities gained confidence that they occupied a less subordinate position vis-a-vis transnational capital than had previously been the case. ${ }^{59}$ When Ascendant workers went on strike in late 2007, the impetus of provincial and central authorities was merely to avoid instability and to get workers back on the line, regardless of the outcome; but by spring of 2010 , they were ready to be much more lenient. As a result, once the Nanhai strike started the higher- level authorities decided to open up more space for insurgent workers to overcome the repressive tendencies of the local state, a tendency that was made apparent when the township union federation physically attacked the strikers. And the provincial union's continuous attention to the plant is an indication that they would like to build up an institutional capacity at the enterprise level that will be resilient enough to overcome the opposition of capital and the local government. Whether they will be able to do this while keeping the genie of autonomous worker power in the bottle remains unclear.

The analysis of these two strikes helps to highlight the utility of my reformulation of the theory of countermovements in understanding how worker insurgency evolved during the first decade of the twenty-first century. Given the background of expanding but diffuse worker resistance throughout the 1990s and early 2000 s, we can see that migrant worker insurgency was high. And yet, there was little decommodification or incorporation that Polanyian theory would lead us to expect. Under conditions of appropriated representation the movement from insurgency to institutionalization is deeply problematic, and as a result worker unrest in China remains high. Indeed, it could be argued that the political effects of insurgency are not immediate, and that pro-labor legislation and possible union reform may take some time in implementation. But this is precisely my point: the framework of the insurgency-institutionalization dialectic allows us to see that while there is massive social resistance to commodification, countermovements are a tendency and do not move inexorably or mechanistically toward some pre-determined end: Politics always intervene. In an era in which the withering of civil society is not restricted to authoritarian countries but is in fact a global phenomenon (Hardt 1995), such a framework should prove useful in studying the dynamics and difficulties of countermovements in other countries.

Additionally, the dynamics of worker unrest changed, as two relatively unique features appeared in the Nanhai strike and other strikes in the summer of 2010. The most significant difference with most previous outbursts of insurgency (including those during the major factory closures in 2008-2009) was that workers were on the offensive and

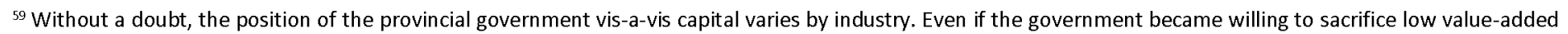

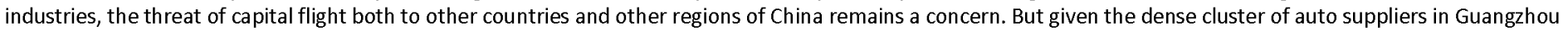
and the relatively high costs of relocating production, the government likely felt greater confidence in dealing with foreign automakers.
} 
that they won economic gains. And second, the issue of union reorganization became more central, an indication of the germination of political consciousness. But there were many ways in which older patterns of resistance continued, both of which are somewhat counter-intuitive. The first is that worker protest remained highly cellular. Despite the fact that there was a major strike wave in which workers were clearly inspired by what was occurring in other factories, there was no coordination among strikers from different factories. The other is that workers' sense of fidelity to the law remains quite strong. In the course of an interview, one Nanhai striker revealed the contradictory consciousness that is prevalent among insurgent workers. On the one hand, he recognized the efficacy of legally ambiguous strikes: “That's right, [the company's internal complaint system] was not at all effective. Stopping work is effective, as soon as we stop work we see the Japanese people, as soon as we stop working the Japanese will immediately ask what the problem is." ${ }^{60}$ And yet, just a few minutes later, the same worker said, “I hope [the union] will teach us about labor laws, so in the future we'll be better able to defend our rights according to normal procedures." ${ }^{11}$ None of the workers from Nanhai expressed discontent with the laws themselves, a remarkable confirmation of the persistence of highly legalistic modes of thought, if not always action, among workers.

In conclusion, a comparison between Nanhai Honda and Ascendant allows us to see the insurgent-institutional dialectic unfolding during the key years of 2007-2011. Up to and during the economic crisis of 2008-2009, the union could not muster an effective institutional response to worker unrest. However, with the 2010 Nanhai strike the higherlevel authorities allowed for the strike to continue in order to overcome the strong state-capital alliance at the local level and to raise workers' wages. A combination of continual insurgency as well as a degree of elite support produced gains that serve as an early indication of the institutional moment of the countermovement. And yet, even if material conditions improved, continual worker disillusionment and the involvement of the provincial union are signs that enterprise- level organizations remain weak, a phenomenon that should cause us to consider how sustainable and "exportable" the compromise at Nanhai really is. Indeed, as one striker at Nanhai implied, it is not just economic but also political issues that underlie generalized worker discontent:

Of course we don't take the same position as those in power ... a lot of people have the same difficulties as us, and have the same thoughts. Actually, the reason our Honda factory ended up [causing a strike wave], is because this is already a social problem, it's not just as simple as raising wages. ${ }^{62}$

The state and union at all levels maintain a steadfast dedication to the isolation of political and economic struggles; whether such a separation will continue to be feasible in practice is unclear.

Acknowledgments A much earlier version of this article was presented as a paper at a panel organized by Joel Andreas at the North American Chinese Sociologists Association in August 2009.I would like to thank the following people for reading and commenting on earlier versions of this article: Fred Block, Dan Buch, Julia Chang, Peter Evans,

\footnotetext{
${ }^{60}$ Interview, July 25, 2010.

61 Ibid.

62 Ibid.
} 
Daniel Immerwahr, Mike Levien, Simon Morfit, Stephen Philion, Tianna Paschel, Alina Polyakova, and Aaron Shaw. The Editors of Theory and Society and two anonymous reviewers also provided helpful feedback. Funding for this research was provided by the University of California's Pacific Rim Research Program and Labor and Employment Research Fund. I would especially like to thank the students of the Wildcat Club for their invaluable research assistance. 


\section{References}

Abolafia, M. (1996). Making markets: Opportunism and restraint on Wall Street. Cambridge: Harvard University Press.

Alimi, E. Y. (2009). Mobilizing under the gun: theorizing political opportunity structure in a highly repressive setting. Mobilization, 14(2), 219-238.

Andrews, K. T. (2004). Freedom is a constant struggle: The Mississippi civil rights movement and its legacy. Chicago: University of Chicago Press.

Blecher, M. (2008). When wal-mart wimped out: globalization and unionization in china. Critical Asian Studies, 40(2), 263-276.

Block, F. (2003). Karl polanyi and the writing of the great transformation. Theory and Society, 32, 275-306.

Blumenthal, D., \& Hsiao, W. (2005). Privatization and its discontents-the evolving Chinese health care system. The New England Journal of Medicine, 353(11), 1165-1170. Massachusetts Medical Society.

Bourdieu, P. (1985). The social space and the genesis of groups. Theory and Society 14(6):723-744.

Burawoy, M. (2003). For a sociological Marxism: the complementary convergence ofAntonio gramsci and Karl Polanyi. Politics \& Society, 31(2), 193-261.

Burstein, P., \& Linton, A. (2002). The impact of political parties, interest groups, and social movement organizations on public policy: some recent evidence and theoretical concerns. Social Forces, 81(2), 380-408.

Cai, Y. (2002). The resistance of Chinese laid-off workers in the reform period. China Quarterly, 170,327-344.

Cai, Y. (2010). Collective resistance in China: Why popular protests succeed or fail. Stanford: Stanford University Press. Chan, A. (2001). China's workers under assault: The exploitation of labor in a globalizing economy (p. xv, 249). Armonk: M.E. Sharpe.

Chan, A. (2007). Organizing Wal-Mart in china: two steps forward, one step back for China's unions. New Labor Forum, 16(2), 87-96.

Chan, J. W. (2009). Meaningful progress or illusory reform?: analyzing China's labor contract Law. New Labor Forum, $18(2), 43-51$.

Chan, D., \& Mok, K.-H. (2001). Educational reforms and coping strategies under the tidal wave of marketisation: a comparative study of Hong Kong and the Mainland. Comparative Education, 37(1), 21-41.

Chan, C. K.-C., \& Pun, N. (2009). The making of a new working class? a study of collective action of migrant workers in south china. China Quarterly, 198, 287-303.

Chan, A., \& Unger, J. (2009). A Chinese state enterprise under the reforms: what model of capitalism? The China Journal, $62,1-26$. 
Chen, F. (2000). Subsistence crises, managerial corruption and labour protests in China. The China Journal, 44, 41-63.

Chen, F. (2003a). Industrial restructuring and workers' resistance in china. Modern China, 29, 237-262.

Chen, F. (2003b). Between the state and labour: the conflict of Chinese trade Unions' double identity in market reform. China Quarterly, 176, 1006-1028.

Chen, F. (2007). Individual rights and collective rights: labor's predicament in china. Communist and PostCommunist Studies, 40, 59-79.

Chen, F. (2009). Union power in China: source, operation, and constraints. Modern China, 35, 662-689.

Choi, Y.-J. (2003). Managerial styles, workforce composition and labor unrest: East Asian-invested enterprises in China. Comparative Sociology, 2(2), 321-354.

Clarke, S., Lee, C.-H., \& Li, Q. (2004). Collective consultation and industrial relations in China. British Journal ofIndustrial Relations, 42(2), 235-254.

Cooney, S., Biddulph, S., Li, K., \& Zhu, Y. (2007). China's new labor contract law: responding to the growing complexity of labour relations in the PRC. University ofNew South Wales Law Journal, 30, 786-801.

Deyo, F. C. (1987). State and labor: Modes of political exclusion in East Asian development. In F. C. Deyo (Ed.), The political economy of the new Asian industrialism (pp. 182-202). Ithaca: Cornell University Press.

Deyo, F. C. (1989). Beneath the miracle: Labor subordination in the New Asian industrialism. Berkeley: University of California Press.

Esping-Andersen, G. (1990). The three worlds ofwelfare capitalism. Princeton: Princeton University Press.

Fan, C. (2006). China's eleventh five-year plan (2006-2010): from "getting rich first" to "common prosperity. Eurasian Geography and Economics, 47(6), 708-723.

Frazier, M. (2010). Socialist insecurity: Pensions and the politics of uneven development in china. Ithaca: Cornell University Press.

Friedman, E., \& Lee, C. K. (2010). Remaking the world of Chinese labour: a 30-year retrospective. British Journal of Industrial Relations, 48(3), 507-533.

Gallagher, M. (2004). Time is money, efficiency is life: the transformation of labor relations in China. Studies in Comparative International Development, 39(2), 11-44.

Gallagher, M. (2005). Contagious capitalism: Globalization and the politics of labor in China. Princeton: Princeton University Press.

Giugni, M. (2004). Social protest and policy change: ecology, antinuclear, and peace movements in comparative perspective. Lanham: Rowman \& Littlefield.

Goldfield, M. (1989). Worker insurgency, radical organization, and new deal labor legislation. The American Political 
Science Review, 83(4), 1257-1282.

Golley, J., \& Meng, X. (2011). Has China run out of surplus labour? China Economic Review, 22(4), 555-572.

Guha, R. (1983a). Elementary aspects ofpeasant insurgency in colonial India. Delhi: Oxford University Press.

Guha, R. (1983b). The prose of counter-insurgency. In R. Guha (Ed.), Subaltern studies II: Writings on south Asian history and society (pp. 1-43). Oxford: Oxford University Press.

Hardt, M. (1995). The withering of civil society. Social Text, 45, $27^{\wedge} 4$.

Harper, P. (1969). The party and unions in communist China. China Quarterly, 37, 84-119.

Hassid, J. (2008). Controlling the media: an uncertain business. Asian Survey, 48(3), 414-430.

Hearn, J. M. (1977). W(h)ither the trade unions in China? Journal of Industrial Relations, 19, 158-172.

Howell, J. (2008). All-China federation of trade unions beyond reform? The slow march of direct elections. China Quarterly, 196, 845-863.

Hsing, Y (2009). The great urban transformation: Politics of land and property in china. Oxford: Oxford University Press. Hurst, W. (2004). Understanding contentious collective action by Chinese laid-Offworkers: the importance of regional political economy. Studies in Comparative International Development, 39(2), 94-120.

Hurst, W. (2009). The Chinese worker after socialism. Cambridge: Cambridge University Press.

Katznelson, I. (1986). Working-class formation: Constructing cases and comparisons. In I. Katznelson \& A. Zolberg (Eds.), Working-class formation: Nineteenth-century patterns in Western Europe and the United States. Princeton: Princeton University Press.

Keck, M., \& Sikkink, K. (1998). Activists beyond borders: Advocacy networks in international politics (p. 228). Cornell University Press.

Koo, H. (2001). Korean workers: The culture and politics of class formation. Ithaca: Cornell University Press.

Kwan, D. Y. K. (1997). Marxist intellectuals and the Chinese labor movement: A study of Deng Zhongxia, 1894-1933. Seattle: University of Washington Press.

Lau, R. W. K. (2003). The habitus and "logic of practice" of China's trade unionists. Issues \& Studies, 39 (3), 75-103. Lee, C. K. (1998). Gender and the South China miracle: Two worlds of factory women. Berkeley: University of California Press.

Lee, C. K. (2000). The "revenge of history:" collective memories and labor protests in North-Eastern China. Ethnography, 1(2), 217-237.

Lee, C. K. (2002). From the specter of Mao to the spirit of the law: labor insurgency in China. Theory and Society, 31, $189-228$. 
Lee, C. K. (2007). Against the law: Labor protests in China's rustbelt and sunbelt. Berkeley: University of California Press.

Leung, P. N., \& Pun, N. (2009). The radicalisation of the New Chinese working class: a case study of collective action in the gemstone industry. Third World Quarterly, 30(3), 551-565.

Li, H., \& Zhou, L.-A. (2005). Political turnover and economic performance: the incentive role of personnel control in China. Journal of Public Economics, 89(9-10), 1743-1762.

Liu, H.-J. (2011). When labor and nature strike back: a double movement saga in Taiwan. Capitalism Nature Socialism, 22(1), 22-39.

McAdam, D. (1982). Political process and the development of black insurgency, 1930-1970. Chicago: University of Chicago Press.

McAdam, D., Tarrow, S., \& Tilly, C. (2001). Dynamics ofcontention. New York: Cambridge University Press.

Metcalf, D., \& Li, J. (2005). Chinese unions: Nugatory or transforming? - An Alice Analysis. Center for Economic Performance.

Mok, K. H. (2000). Marketizing higher education in post-Mao China. InternationalJournal ofEducational Development, $20(2), 109-126$.

Piven, F. F., \& Cloward, R. (1977). Poor people's movements: Why they succeed, how they fail. New York: Vintage. Polanyi, K. (1944). The great transformation: The political and economic origins of our time. Boston: Beacon.

Rueschemeyer, D., Stephens, E. H., \& Stephens, J. D. (1992). Capitalist development and democracy. Chicago: University of Chicago Press.

Schock, K. (2005). Unarmed insurrections: People power movements in nondemocracies. Minneapolis: University of Minnesota Press.

Sheehan, J. (1998). Chinese workers: A new history. London: Routledge.

Silver, B. J., \& Arrighi, G. (2003). Polanyi's "Double movement": the belle Epoques of British and U.S. Hegemony compared. Politics \& Society, 31(2), 325-355.

Silver, B. J., \& Zhang, L. (2009). China: Emerging epicenter of world labor unrest? In H. Hung (Ed.), China and the transformation ofglobal capitalism. Baltimore: Johns Hopkins University Press.

Slater, D. (2009). Revolutions, crackdowns, and quiescence: communal elites and democratic mobilization in Southeast Asia. The American Journal of Sociology, 115(1), 203-254.

Snow, D., \& Cress, D. (2000). The outcomes of homeless mobilization: the influence of organization, disruption, political mediation, and framing. The American Journal of Sociology, 105(4), 1063-1104.

Solinger, D. J. (1999). Contesting citizenship in urban China peasant migrants, the state, and the logic of the market (p. xix, 444). Berkeley: University of California Press. 
Solinger, D. J. (2001). Why we cannot count the "unemployed". China Quarterly, 167, 671-688.

Solinger, D. J. (2009). States' gains, labor's losses: China, France, and Mexico choose global liaisons, 1980-2000. Ithaca: Cornell University Press.

Soule, S., McAdam, D., McCarthy, J., \& Su, Y. (1999). Protest events: cause or consequence of state action? The U.S. Women's Movement and federal congressional activities, 1956-1979. Mobilization, 4 (2), 239-256.

Tarrow, S. (1998). Power in movement: Social movements and contentious politics. Cambridge: Cambridge University Press.

Taylor, B., \& Li, Q. (2007). Is the ACFTU a union and does it matter? Journal ofindustrial Relations, 49 (5), 701-715.

Tilly, C. (1999). From interactions to outcomes in social movements. In M. Giugni, D. McAdam, \& C. Tilly (Eds.), How social movements matter (pp. 253-270). Minneapolis: University of Minnesota Press.

Tilly, C. (2004). Social movements, 1768-2004. Boulder: Paradigm Publishers.

Tilly, C., \& Tarrow, S. G. (2007). Contentious politics. Boulder: Paradigm Publishers.

Wang, S. (2008). The great transformation: the double movement in China. Boundary 2, 35(2),15-47.

Wang, H., Appelbaum, R. P., Degiuli, F., \& Lichtenstein, N. (2009). China's new labour contract law: is china moving towards increased power for workers? Third World Quarterly, 30(3), 485-501.

Yu, X. (2008). Workplace democracy in China's foreign-funded enterprises: a multilevel case study of employee representation. Economic and Industrial Democracy, 29, 274-300.

Zhang, L. (2008). Lean production and labor controls in the Chinese automobile industry in an age of globalization. International Labor and Working-Class History, 73(1), 1-21.

Eli Friedman is Assistant professor of International and Comparative Labor at Cornell University's ILR School. His general interests focus on the social and political consequences ofthe emergence ofa new class of migrant workers in China. He has done research on worker protest, NGOs, unions, and more recently on migrant education and teachers' work in Beijing, Guangzhou, and Chengdu. His most recent publication is, "Getting Through the Hard Times Together? Chinese Workers and Unions Respond to the Economic Crisis," Journal ofIndustrial Relations (2012) Other articles by Friedman have appeared in Mobilization, British Journal ofIndustrial Relations, and Journal ofDemocracy. 